\title{
GÊNERO, ESCRITURA E IDENTIDADE EM ISABEL ALLENDE ${ }^{1}$ \\ GÉNERO, ESCRITURA E IDENTIDAD EN ISABEL ALLENDE
}

\author{
Cinara Ferreira Pavani ${ }^{2}$
}

Resumo: Este estudo propõe a análise do romance Eva Luna (1987), de Isabel Allende, sob a perspectiva das relações entre gênero, escritura e identidade. Parte-se do pressuposto de que a escritura possibilita a construção da identidade da protagonista, uma vez que, através da narração de histórias, ela resolve problemas, relaciona-se com seus afetos e se torna escritora. Desse modo, a personagem feminina do romance de Allende conquista sua autonomia na esfera pública da sociedade, espaço em que a mulher precisou transpor várias barreiras para ocupar um lugar.

Palavras-chave: estudos culturais de gênero, identidade, literatura feminina.

Resumen: Este estudio propone el análisis de la novela Eva Luna (1987), de Isabel Allende, a partir de la perspectiva de las relaciones de género, escritura e identidad. Se parte del presupuesto de que la escritura posibilita la construcción de la identidad de la protagonista, ya que, a través de la narración de historias, ella resuelve problemas, se relaciona con sus afectos y se vuelve escritora. De este modo, el personaje femenino de la novela de Allende conquista su autonomía en la esfera pública de la sociedad, espacio en el que la mujer necesitó superar distintas barreras para ocupar un lugar.

Palabras clave: estudios culturales de género, identidad, literatura femenina.

\footnotetext{
1 Este estudo constitui um recorte da tese de Doutorado intitulada Uma Sheherazade latinoamericana: Eva Luna entre histórias e história, defendida em 2004, pela UFRGS.

2 Professora da Universidade Federal do Rio Grande do Sul.

Organon, Porto Alegre, nº 53, julho-dezembro, 2012, p. 97-108
} 
Cuando pienso que todo me falla, que la vida no es más que un teatro absurdo sobre el viento armado, sé que la palabra siempre está ahí, dispuesta a devolverme la fe en mi misma y en el mundo. Rosario Ferré

Gênero, escritura e identidade são categorias que se interligam no âmbito das discussões sobre a literatura produzida por mulheres no século XX. Os estudos de gênero apontam que, em geral, a literatura escrita sob a ótica feminina é resultado de um processo de recuperação de uma voz silenciada na história, envolvendo a conquista tanto do espaço da escritura, quanto da construção da identidade. Nessa perspectiva, a chilena Isabel Allende destaca-se tanto por eleger a condição da mulher e a escrita como objetos de sua representação, como por ter sido uma das primeiras escritoras latino-americanas a conquistar um lugar no mercado editorial mundial, com o romance A casa dos espíritos (1982). Este estudo pretende mostrar como Allende problematiza a questão do gênero, da escritura e da identidade, a partir da análise do seu terceiro romance, intitulado Eva Luna (1987).

A obra narra a história de uma personagem que se constitui enquanto sujeito a partir da capacidade de narrar. O livro estrutura-se em torno de narrativas que se entrelaçam e têm como fio condutor a vida de Eva Luna. A partir da apropriação da palavra, a personagemnarradora supera problemas de todas as ordens, desde a orfandade, a fome e a exploração, até a violência. Nesse sentido, pode-se compará-la à célebre narradora Sheherazade, de As mil e uma noites ${ }^{3}$, a qual se salva da morte através do poder da palavra.

A trajetória percorrida pela protagonista na construção de sua identidade pode ser dividida em dois momentos distintos: antes e depois do aprendizado da escrita. Enquanto não sabe ler, a memória e os elementos do cotidiano servem de ponto de partida para a invenção de seus contos. Depois, a leitura será fonte de histórias e fator de amadurecimento de sua capacidade de narrar.

No primeiro capítulo da obra, a narradora apresenta-se a partir

3 As mil e uma noites / [versão de] Antoine Galland; tradução de Alberto Diniz; apresentação de Malba Tahan. 2.ed. Rio de Janeiro: Ediouro, 2000. 2 v.

Organon, Porto Alegre, n⿳⺈ 53, julho-dezembro, 2012, p. 97-108 
de lembranças do que sua mãe lhe contava, situando o leitor em relação às suas origens. A personagem inicia a narrativa referindose ao próprio nome, escolhido pela mãe: "Chamo-me Eva, que quer dizer vida, segundo um livro que minha mãe consultou para escolher meu nome" (ALLENDE, 1987, p. 7). O livro consultado aponta para um provável dicionário de nomes, mas sugere também um intertexto com a Bíblia, que tem sua origem na oralidade. A referência ao nome e ao seu significado revela a importância dada à palavra e à intenção que nela se imprime. Ele não foi escolhido ao acaso, mas com uma intencionalidade, que se faz importante na trajetória da personagem. Antevendo que a filha precisaria de forças em sua passagem pela vida, Consuelo afirma no seu nascimento: "Ela se chamará Eva, para que tenha vontade de viver” (ALLENDE, 1987, p. 27).

A convivência com a progenitora, apesar de breve, é de fundamental importância na vida da protagonista, pois é a sua única referência familiar. Nada possuindo de seu, Consuelo deixa-lhe como herança suas histórias e o conhecimento de que as palavras podem transformar a realidade:

As palavras são grátis, costumava dizer, e apropriava-se delas, eram todas suas. Semeou em minha cabeça a ideia de que a realidade não é apenas como percebida na superfície, possuindo também uma dimensão mágica e, tendo-se vontade, é legítimo exagerá-la e dar-lhe cor, para que a passagem por esta vida não se torne tão tediosa. As personagens que evocava no encantamento de seus contos são as únicas recordações nítidas que conservo de meus primeiros anos, porque o resto pereceu envolto em uma névoa (...) (ALLENDE, 1987, p. 29).

Zumthor defende a tese de que a voz estabelece ou restabelece a alteridade, que funda a palavra do sujeito (1993, p. 97). Esse princípio permite dizer que o narrar em Eva Luna é um modo de relação com o outro, fundamental para a constituição do sujeito. A partir das histórias que ouve a mãe contar na intimidade do quarto, as quais rememora no decorrer da narrativa, a menina aprende a arte de narrar, habilidade que a distinguirá mais tarde e possibilitará fazer ouvir sua voz, através da escritura.

A mãe de Eva morre com a garganta perfurada por um osso de galinha, quando a menina tem apenas seis anos de idade e passa a ser cuidada por sua madrinha que a explora, empregando-a numa casa de ricos. A morte com uma perfuração na garganta sugere uma ligação entre o cessar Organon, Porto Alegre, n⿳⺈ 53, julho-dezembro, 2012, p. 97-108 
da existência e o cessar da capacidade de falar, de narrar. Entretanto, a morte do corpo não silencia a voz de Consuelo, pois ela continuará a ser pronunciada pela filha. A intimidade do quarto ainda será um espaço de carinho e de narrativas, através do contato com Elvira, a cozinheira da primeira casa em que trabalha: "Enrolava-me junto de Elvira e oferecialhe uma história, se me deixasse ficar com ela" (ALLENDE, 1987, p. 67).

Eva Luna aprimora sua capacidade de narrar, a partir das situações e dificuldades que a vida vai lhe apresentando. Aos nove anos de idade, por exemplo, quando já não tem mais a mãe ao seu lado, Eva conhece Huberto Naranjo, que lhe dá comida e um lugar para dormir. Em troca, ela lhe oferece uma história: "Encolhi-me entre os jornais e ofereci-lhe uma história, em pagamento por tantas e tão finas atenções" (ALLENDE, 1987, p. 72).

Além de ser fonte de narrativas, a memória é o elemento que possibilita que as histórias atualizadas perdurem no tempo. A memória só passa a ter um papel secundário no processo criativo da personagem, assim como nas civilizações em geral, quando ela aprende a ler e a escrever. Com o aprendizado da escrita, torna-se possível a permanência e a interferência no mundo através do registro no papel. $\mathrm{O}$ que antes exigia o esforço da memória, pode ser relembrado também através da leitura: "A possibilidade de escrever permitiu que prescindisse das rimas para recordar, e pude forjar histórias com incontáveis personagens e aventuras..." (ALLENDE, 1987, p. 164). Entretanto, isso não quer dizer que a memória não continue desempenhando um papel importante na narrativa. Zumthor assinala que a fixação pela e na escritura de uma tradição que foi oral não significa o fim nem a marginalização desta. Para o teórico, instaura-se uma simbiose ou pelo menos certa harmonia entre oralidade e escrita, na medida em que o oral se escreve e o escrito se pretende uma imagem do oral (1993, p. 154).

Nessa perspectiva de análise, é fundamental lembrar que a conquista da escritura é um passo decisivo no processo de emancipação das mulheres. Como apontam Duby e Perrot, a mulher sempre teve voz, no entanto, não tinha acesso à única linguagem que realmente contaria para que sua voz fosse ouvida na sociedade - a linguagem escrita (1994). ${ }^{4}$ Como se observa em diferentes momentos da história da

4 Conforme indicam os autores, "desde o dia em que os deuses criaram Pandora, a primeira mulher, dando-lhe uma voz, pelos quatro cantos do mundo surgiram as vozes femininas". 
humanidade, aquele que não escreve não influi, não transforma e não é ouvido, restando-lhe apenas a obediência.

Nos grupos marginalizados, como o das mulheres, a escrita ficcional e a escrita histórica são de vital importância no processo de questionamento das assimetrias do poder, bem como da constituição da identidade. Sob esse prisma, reforça-se a ideia apontada por Schmidt de que é pelo ou no discurso, como instância de articulação entre o nível linguístico e o extra-linguístico, que se opera a construção/destruição de identidades - textuais, históricas, políticas. As identidades são concebidas, conforme a autora, como movimentos contínuos/descontínuos das relações que sujeitos, comunidades, nações estabelecem imaginariamente com o outro, o que garante sua autoconstituição e sua inserção dentro de certas condições sócio-históricas e discursivas que são, elas próprias, sustentáculos daquelas relações (2000, p. 102-103). Desse modo, torna-se necessário examinar como se dá no romance de Allende a construção da identidade da personagem narradora, a partir do acesso ao código escrito.

Em Eva Luna, identidade e escritura estão imbricadas na personagem/narradora que, ao construir sua escrita, constrói-se enquanto sujeito de sua história. Eva Luna tem contato com a escrita por intermédio de Riad Halabí, que a acolhe em sua casa quando ela tem mais ou menos 13 anos de idade. Ao lhe dar um registro de nascimento, Riad confere-lhe existência no meio social: "Riad Halabí deu-me várias coisas fundamentais para transitar através de meu destino e, entre elas, duas muito importantes: a escrita e um certificado de existência" (ALLENDE, 1987, p. 170). O fato de aprender o código escrito na mesma época em que é registrada sugere uma relação entre narrar e existir, confirmada no sentimento de plenitude que o ato de escrever proporciona à personagem: "Escrever era o melhor que já acontecera na vida, eu estava eufórica, lia em voz alta, andava com o caderno debaixo do braço para usá-lo a cada momento, anotava pensamentos, nomes de flores, ruídos de pássaros, inventava palavras" (ALLENDE, 1987, p. 164).

As primeiras leituras da protagonista constituíram-se de almanaques, revistas de cinema e novelas românticas, as quais transformava em histórias mais interessantes e ricas de significado, pois logo percebeu que as mesmas eram medíocres e possuíam uma forma pouco variável:

Organon, Porto Alegre, ํำ 53, julho-dezembro, 2012, p. 97-108 
"Em pouco tempo, na terceira página, eu já adivinhava o argumento e, para distrair-me, modificava tudo, desviando o enredo para um desenlace trágico, muito diferente do idealizado pelo autor e mais de acordo com minha incurável tendência à morbidez e violência” (Eva Luna, p. 165).

Para tornar essas histórias mais significativas, Eva Luna utiliza elementos da realidade assimilados pelo contato com o rádio e o jornal: "Eu salpicava o tema com ingredientes violentos, extraídos do rádio ou da crônica policial e também com os conhecimentos adquiridos às furtadelas nas ilustrações dos livros didáticos da Senhora" (Eva Luna, p. 165). Segundo Bakhtin, a linguagem literária é um fenômeno profundamente original, assim como a consciência linguística do literato que lhe é correlata; nela, a diversidade intencional torna-se plurilíngue: trata-se não de uma linguagem, mas de um diálogo de linguagens (1997, p. 101). O que determina a diferença entre as linguagens é o lugar de enunciação na situação comunicativa. Ao utilizar linguagens distintas, como as do rádio, da crônica policial e das ilustrações de livros didáticos, a narradora instaura o diálogo que torna sua criação plurilíngue. Assim, o contato com diferentes linguagens, como uma enciclopédia e os conhecimentos de sua professora, possibilita-lhe o domínio cada vez maior das palavras:

Valendo-me de uma enciclopédia e dos conhecimentos de minha professora, eu viajava pelo mundo. Em troca, tornei-me uma nulidade com os números. Se não aprender a multiplicar, como vou poder confiarlhe o armazém? reclamava o turco. Eu não fazia muito caso, preocupada apenas em conseguir o maior domínio das palavras. Lia o dicionário com paixão e podia passar horas em busca de rimas, descobrindo antônimos e resolvendo palavras-cruzadas (ALLENDE, 1987, p. 200).

A intimidade com as palavras é um fator importante na análise do desenvolvimento da consciência da personagem, porque, através da leitura e da produção escrita, ela passará a dar significado a sua vida. Segundo Lev Vygotsky, estudioso das questões cognitivas, o pensamento e a linguagem são a chave para a compreensão da natureza da consciência humana, visto que refletem a realidade de uma forma diferente daquela da percepção. As palavras desempenham um papel central não só no desenvolvimento do pensamento, mas também na evolução histórica da consciência como um todo (1993, p.131-132). 
Dessa forma, a escrita assume um papel estabilizador das emoções e organizador da compreensão de mundo de Eva:

Sempre ocupada, não tinha ânimo para ocupar-me de mim, porém em minhas histórias apareciam ânsias e inquietudes que ignorava estarem em meu coração. (...) Eu passava parte da noite escrevendo e gostava tanto disso, que as horas passavam sem que me desse conta, e às vezes levantava pela manhã com os olhos avermelhados. No entanto, eram as melhores horas. (...) Em certas ocasiões, sentia que esse universo fabricado pelo poder da imaginação tinha contornos mais firmes e duráveis do que a região confusa onde perambulavam os seres de carne e osso que me rodeavam (ALLENDE, 1987, p. 201-2).

A leitura e a habilidade de narrar não só servem como meio de organizar a experiência de Eva mas também servirão, mais tarde, como forma de trabalho. Quando abandona Água Santa, lugar em que vive longe das adversidades materiais por algum tempo, e retorna à capital não nomeada na obra, a protagonista não possui nenhuma garantia econômica. Na cidade, ela é acolhida por Melécio/Mimi, que a ajuda a transpor as dificuldades financeiras. É o amigo transexual que irá incentivá-la a escrever como um meio de sobrevivência, pois, inicialmente, a personagem não acredita nessa possibilidade:

$\mathrm{Na}$ verdade, eu não tinha certeza de que isso tivesse alguma aplicação prática, pois até então só me servira para dar um pouco de colorido à vida e escapar para outros mundos, quando a realidade se tornava insuportável; contar histórias parecia-me um ofício superado pelos progressos do rádio, da televisão e do cinema. Eu pensava que tudo quanto fosse transmitido pelas ondas ou projetado em uma tela fosse verídico e que, em troca, minhas narrativas eram quase sempre um amontoado de mentiras, que nem eu mesma sabia de onde tirava (ALLENDE, 1987, p. 227).

Tornar-se uma profissional da escrita significa conquistar um lugar ocupado durante muito tempo somente por homens. A tematização da problemática do gênero, em Eva Luna, traz à tona as dificuldades enfrentadas pelas mulheres, no século XX, na conquista tanto de um espaço no mercado editorial quanto na crítica literária. Segundo aponta Virgínia Woolf, até o final do século XIX, a mulher não foi encorajada 
a desenvolver as suas inclinações estéticas e as poucas que ousaram penetrar nessa área de domínio masculino foram ridicularizadas e repudiadas em seu meio social (1985).

É significativo o fato de Mimi, um ser andrógino, colocar-se como incentivador da independência de Eva Luna. Justamente por ter sua voz desconsiderada na sociedade, Mimi identifica-se com a amiga e busca ajudá-la a transpor seu estado de subjugação. Mimi argumenta a partir do ponto de vista do oprimido, ao dizer a Eva que, sendo escritora, ela não "precisaria levantar tão cedo e ninguém ficaria dando-lhe ordens" (ALLENDE, 1987, p. 240).

Eva Luna deseja tornar-se escritora, mas só decide investir nessa vontade quando, ao ser assediada por um general, sente-se obrigada a deixar o emprego em uma fábrica de uniformes militares: “- Não há mal que por bem não venha - sentenciou Mimi, ao constatar que a roda da fortuna dera meio giro, colocando-me no caminho em que ela considerava que eu sempre deveria estar. - Agora, você poderá escrever a sério" (ALLENDE, 1987, p. 267). É Mimi, novamente, quem a incita a escrever, posto que acredita que todos devem descobrir e dedicar-se ao seu dom. $\mathrm{O}$ seu é ser atriz de novela: "Acabava de debutar em uma novela de televisão, fazendo o papel de Alejandra, a mulher má, rival de Belinda, uma jovem cega que terminaria recuperando a visão - como sempre acontece em tais casos - para casar-se com o galâ" (ALLENDE, 1987, p. 267).

$\mathrm{O}$ incentivo de Mimi à Eva Luna é recompensado pela sua inclusão como protagonista da novela que escreve, intitulada Bolero. A personagem vê-se na literatura, simbolizando o leitor que, ao se identificar com uma personagem, tem no texto literário um espelho que permite o seu autoconhecimento. Nesse sentido, como forma de arte em que a cultura de cada época se corporifica, a literatura dá forma e divulga os valores que dinamizam uma sociedade ou uma civilização. Assim, tanto o indivíduo quanto o grupo social têm na literatura um meio de conhecer a si mesmo e ao mundo. Mimi compra-lhe uma máquina de escrever e discute com Eva o enredo ideal:

Era uma máquina de escrever. Para que você comece a trabalhar, disse. Passamos parte de noite sentadas na cama, bebendo vinho, comendo os pastéis e discutindo o enredo ideal, uma mistura de paixões, divórcios, bastardos, bons e maus, ricos e pobres, capaz de prender o telespectador desde o primeiro instante e mantê-lo prisioneiro da tela durante duzentos comovedores capítulos (ALLENDE, 1987, p. 268).

Organon, Porto Alegre, n⿳0 53, julho-dezembro, 2012, p. 97-108 
$\mathrm{O}$ fragmento transcrito remete à ideia de que os temas ditos universais prendem a atenção do telespectador, ou seja, a empatia do receptor dependerá do grau de identificação suscitado pelo produto cultural. Inicialmente, parece que Eva escreverá uma novela nos moldes tradicionais, mas logo em seguida percebe-se que sua escrita subverte os finais previsíveis e as situações açucaradas costumeiras no gênero. Eva recebe recomendações de como deveriam ser escritos os capítulos da sua novela. No entanto, o processo criativo faz com que esqueça tais diretrizes:

Ninguém me interrompeu e passei o dia inteiro escrevendo, tão absorta que até esqueci de comer. (...) Prossegui nesse ritmo, esquecida das recomendações recebidas: os scripts são organizados em duas colunas, cada capítulo tem vinte e cinco cenas, muito cuidado com as mudanças de cenário, pois estes saem muito caros, e com falas longas, que deixam os atores confusos, cada frase importante é repetida três vezes e o enredo deve ser simples partindo-se do pressuposto de que o povo é burro (ALLENDE, 1987, p. 270).

A crítica observada em relação à previsibilidade das novelas de televisão pode ser estendida ao próprio papel da mulher na sociedade. Eva Luna revela-se transgressora tanto em sua forma de agir, diferente do que a sociedade espera da mulher, quanto na maneira de escrever, confirmando a hipótese de que sua escrita é um dos meios de construção de sua identidade. A personagem pressente a mudança que a escrita operará em sua vida:

Desde que a professora Inês me tinha ensinado o alfabeto, eu escrevia quase toda a noite, mas senti que aquela era uma ocasião diferente, algo que poderia alterar o meu rumo. Preparei um café forte e instaleime diante da máquina. Peguei uma folha de papel, alva e em branco, como um lençol recém lavado para fazer amor, e a introduzi no rolo (ALLENDE, 1987, p. 269).

A comparação entre a folha de papel em que passará a escrever, alva e em branco, com um lençol recém lavado para fazer amor alude a uma mudança de perspectiva do papel da mulher que, de objeto de uma história narrada por outrem, passa a ser sujeito de uma história contada por ela mesma. A conquista de um espaço na sociedade através da escritura coincide com a participação ativa em outras áreas, como no campo sexual, simbolizado pelo lençol recém lavado.

Organon, Porto Alegre, n 53, julho-dezembro, 2012, p. 97-108 
O fato de assumir a escrita como profissão permite que Eva reconstrua sua vida, pois o que passa a escrever é a sua própria história:

Acreditei que aquela página esperava vinte e tantos anos por mim, que eu vivera apenas para esse instante, e desejei que a partir desse momento o meu único ofício fosse o de captar as histórias suspensas no ar mais sutil, para torná-las minhas. Escrevi meu nome, e em seguida as palavras acudiram sem esforço, uma coisa enlaçada a outra e outra mais (ALLENDE, 1987, p. 269).

A narradora afirma iniciar a narrativa escrevendo o seu próprio nome, confirmando que o romance que lemos é o escrito pela personagem: "Chamo-me Eva..." (ALLENDE, 1987, p. 7). Assim, através do resgate do passado e do registro do presente, configuram-se a escrita e a identidade de Eva:

As personagens desprenderam-se das sombras onde haviam permanecido ocultas durante anos e surgiram à luz daquela quartafeira, cada uma com o seu rosto, sua voz, suas paixões e obsessões. Puseram-se em ordem os relatos arquivados na memória genética desde antes de meu nascimento e muitos outros, registrados durante anos em meus cadernos. Comecei a recordar fatos muito distantes, recuperei as narrativas de minha mãe, quando vivíamos entre os débeis mentais, os cancerosos e os embalsamados do Professor Jones (ALLENDE, 1987, p. 269).

O romance em análise, portanto, constitui-se a partir da palavra da narradora sobre si mesma e sobre o mundo. Nesse sentido, pode-se compará-la à personagem dostoievskiana que, na visão de Bakhtin, não é uma imagem objetiva, mas um discurso pleno, uma voz pura (1997, p. 51). Para o teórico russo, a vida autêntica do indivíduo só é acessível a um enfoque dialógico, diante do qual ele responde por si mesmo e se revela livremente (1997, p. 59). O fato de Eva Luna conduzir a narração de sua história possibilita a condução da sua própria existência. A protagonista é sujeito de sua história, não se deixando levar e construir por outra voz, ou seja, é agente do seu próprio discurso e não um objeto mudo do discurso alheio.

Em suma, Eva Luna é uma obra de cunho feminista que traz à tona problemas relativos ao papel da mulher na sociedade atual e aos 
meios de emancipação e construção da sua identidade. Sob a ótica dos estudos sobre literatura escrita por mulheres, é interessante observar que Eva torna-se escritora e, em consequência, senhora de sua vida, de forma gradativa, pois, inicialmente, apenas conta histórias ouvidas na infância; depois, recria oralmente as narrativas que ouve no rádio e lê nos folhetins e livros, escrevendo a sua própria novela, intitulada Bolero, somente no final da obra. A referida evolução no modo de narrar da protagonista pode ser relacionada à imagem da travessia, que pressupõe um caminho a ser percorrido. O trajeto trilhado por Eva Luna simboliza a travessia empreendida pelas mulheres na sociedade ocidental que, apenas no século XX, conquistaram direitos que legitimaram sua ação e criação no âmbito público.

\section{BIBLIOGRAFIA}

ALLENDE, Isabel. Del ofício de la escritura. Disponível em: http:// www.clubcultura.com/clubliteratura/clubescritores/allende. Acesso em: setembro de 2004.

. Eva Luna. Rio de Janeiro/São Paulo: Record, 1987.

ARAÚJO, Helena. Narrativa femenina latinoamericana. Hispamerica. New Jersey, 1979.

AS mil e uma noites / [versão de] Antoine Galland; tradução de Alberto Diniz; apresentação de Malba Tahan. 2. ed. Rio de Janeiro: Ediouro, 2000. $2 \mathrm{v}$.

BAKHTIN, M. Problemas da poética de Dostoievski. Rio de Janeiro: Forense Universitária, 1997.

. Questões de literatura e de estética. São Paulo: UNESP, 1993.

COELHO, Nelly Novaes. Literatura: arte, conhecimento e vida. São Paulo: Peirópolis, 2000.

DUBY, Georges \& PERROT, Michelle. A história das mulheres. Lisboa: Editora Afrontamento, 1994. v.1, 2 e 3.

FUNCK, Susana Bornéo. Da questão da mulher à questão do gênero. In:___ (Org.) Trocando ideias sobre a mulher e a literatura. Florianópolis: UFSC, 1994

HALL, Stuart. A identidade cultural na pós-modernidade. Rio de Janeiro: DP\&A, 2003.

Organon, Porto Alegre, nº 53, julho-dezembro, 2012, p. 97-108 
SCHMIDT, Rita Terezinha. Em busca da história não contada ou: o que acontece quando o objeto começa a falar? In: INDUSRKY, Freda. Discurso, memória e identidade. Porto Alegre: Sagra-Luzzato, 2000.

. Repensando a cultura, a literatura e o espaço da autoria feminina. In: NAVARRO, Márcia H. (Org.) Rompendo o silêncio. Gênero e literatura na América Latina. Porto Alegre: UFRGS, 1995. Col. Ensaios.

VYGOTSKY, Lev S. Pensamento e linguagem. São Paulo: Martins Fontes, 1993.

WOOLF, Virgínia. Um teto todo seu. Rio de Janeiro: Nova Fronteira, 1985.

ZUMTHOR, Paul. A letra e a voz. A literatura medieval. São Paulo: Companhia das Letras, 1993.

Recebido em: 10/11/2012. Aprovado em: 14/11/2012. 